Research Artide

\title{
GOOD CORPORATE GOVERNANCE MECHANISMS IN MEASURING QUALITY OF FINANCIAL STATEMENTS AND TRANSFER INVESTOR LEVELS
}

\author{
Syafrida Hani and Hafsyah \\ Lecture of Economic Faculty, University of Muhammadiyah Sumatera Utara, \\ Medan, North Sumatera, Indonesia \\ DOI: http://dx.doi.org/10.24327/ijrsr.2017.0805.0280
}

\begin{tabular}{l}
\hline ARTICLE INFO \\
\hline Article History: \\
Received $18^{\text {th }}$ February, 2017 \\
Received in revised form $10^{\text {th }}$ \\
March, 2017 \\
Accepted $06^{\text {th }}$ April, 2017 \\
Published online $28^{\text {th }}$ May, 2017 \\
\hline
\end{tabular}

Key Words:

Accounting Conservatism, Earnings Management, Board of Directors, Audit Committee, Board of Commissioners, Institutional Ownership.

\begin{abstract}
This study aims to develop a theory of determining the quality of financial statement reports that can increase investor confidence in financial information presented by management. This research would like to find the role of good corporate governance in improving the quality of financial statements as measured by accounting conservatism and earnings management, then it will be seen how the quality ability of financial statement can influence investor confidence level. The result of the research did not find the influence of corporate governance mechanism on the quality of financial statements. However, the simultaneous test results found that corporate governance mechanisms and the quality of financial statements affect the level of investor confidence. Profit management as an indicator of the quality of financial statements negatively affects the level of investor confidence. But accounting conservatism declared no effect on the level of investor confidence. The results of the test with path analysis found that the variables that have a direct influence of the mechanism of good corporate governance is the ownership of the institution, while other variables have no influence either directly or indirectly.
\end{abstract}

Copyright () Syafrida Hani and Hafsyah, 2017, this is an open-access article distributed under the terms of the Creative Commons Attribution License, which permits unrestricted use, distribution and reproduction in any medium, provided the original work is properly cited.

\section{INTRODUCTION}

Investors will favor companies that have a high level of profitability. However, high profit information is sometimes presented because of the impact of limited management in selecting and applying the company's accounting policies. Accounting standards as guidelines for presentation of financial statements have loopholes that management can use to manage earnings in accordance with management interests. So the financial statements as a fundamental foundation in making financial decisions should be able to provide relevant and accurate information in accordance with the needs of users of the report. Investors, as one of the parties concerned about the company's financial statements, in making investment decisions not only require information that is fundamental. Qualified financial statements will be the desire of every investor, because it will guarantee the level of investor confidence in the company's performance.

Research on measuring the quality of financial statements has been done a lot, various indicators have been used in measuring the quality of financial statements. Chtorou, Bedard, and Courteau (2001) have investigated that corporate governance practices have an influence on the quality of financial information that is publicly announced. Qualified financial statements can be fully accounted for by the company's management, both on the numbers presented, including the recognition and measurement.

In the Statement of Financial Accounting Concepts (SFAC) no. 2 quality information that ensures that information is reasonably free from error and bias and honestly presents what it is intended to express. The size of the quality of financial statements intuitively can be measured by conservatism and possible manipulation of financial statements typically measured by earnings management. Measuring the quality of financial statements with conservatism because conservatism is considered an obstacle to producing quality financial statements and proxied with non-operating accruals (Watts, 2003). Earnings management as a tool in measuring the quality of financial statements will ensure that the reporting is presented not only intended for the interests of a particular party but rather put forward on the real conditions that occur.

The company's troubled financial condition can encourage managers to manage the level of accounting conservatism. Users of financial statements need to understand the possibility that changes in accounting profit in addition to being 
influenced by the performance of managers can also be influenced by the accounting conservatism policies pursued by managers. Accounting conservatism is based on four issues of contracting, litigation, taxation, and regulation (watts 2003). This will encourage management to use certain techniques to present the report, so that between conservatism and earnings management detected will inhibit the presentation of quality financial statements in accordance with the expectations of all interested parties.

This study wanted to examine how corporate governance mechanism as a good management measurement can affect the quality of financial statements presented by the company to gain trust from investors. From the test results will be known how the relationship of corporate governance mechanisms to investor confidence. Is the quality of financial statements in this case accounting conservatism and earnings management is an intervening variable for corporate governance mechanisms to investor confidence. So it is known whether the mechanism of corporate governance has a direct or indirect relationship to investor confidence.

The results of this study will generally provide input in the development of theory in measuring the level of investor confidence, as more theories generated by research will help business actors and market participants to find various models in improving the quality of financial statements to increase investor confidence. Specifically this research will describe the determinants of the quality of financial statements from the aspect of good corporate management, then the corporate governance mechanism is considered as the right measure to be able to explain whether or not the management of the company. The difference in the results of previous studies of corporate governance mechanisms to accounting conservatism and earnings management also underlies the idea of this study, so it is worthy to be reexamined. The results of Coller and Gregory's (1999) study reveal that the more members of the board of commissioners in a company, the monitoring function of the board of directors can be run better, so that the company will avoid fraudulent financial reporting. While Yermack (1996) and Jensen (1993) found the number of boards of commissioners as one of the corporate governance mechanisms negatively affect the relationship between accounting conservatism and firm value.

The results of this study is expected to benefit the company to be able to measure the extent to which the company's management has given confidence to investors, while for investors can be a reference in measuring the quality of a company for the accuracy of decision making in investing. This research also wishes to contribute to the development of accounting science and encourage subsequent researchers to make further study of good corporate management to ensure the quality of financial statements required by investors and other interested parties to the company.

\section{Theoretical Framework}

Financial statements are declared qualified if current year earnings can be a good indicator of future corporate earnings (Lev and Thiagarajan, 1993). So the earnings information should clearly reveal how the recognition of revenues and costs are accurately measured according to the actual conditions. Freedom in the selection of accounting policies allows management to manage its information for the interests of certain parties so that the report becomes conservative and tends to take profit management measures to meet the needs and expectations of stakeholders.

The concept of conservatism is an act that recognizes costs and losses faster, recognizes income and profit more slowly, assesses assets with the lowest value, and recognizes the obligation with the highest value. Work and Tearney (1997) states that conservatism is an attempt to select acceptable public accounting methods that will result in the recognition of income as slowly as possible, the recognition of expense as soon as possible, lower asset valuation and higher liability assessment. If accruals are negative, profit is classified as conservative, which is due to lower earnings from cash flow earned by the company in a given period of Givoly and Hayn (2002).

There are three characteristics of conservative accounting according to Zhang (2000) which can be seen from the disclosure of the average book value is smaller than the market value, average earnings less than or equal to economic income when long-term growth exceeds or equal to zero and book rate of Average return is greater than the discount rate. Similarly Ross (2003) states conservatism is the difference in the treatment demanded for the recognition of profit or loss, accounting conservatism arises from incentives related to contract costs, litigation, taxes and politics that benefit the company to reduce agency costs and reduce excessive payments to parties - parties such as managers, shareholders, courts and government.

Company management can be expressed through the implementation of good corporate governance. The corporate governance mechanism is proxied by the size of the board of directors, the size of the board of commissioners, the size of the audit committee, the number of independent commissioners, directors turnover and institutional ownership, managerial ownership, labor inspection (Chtourou, 2001; Cornett, 2008; Garcia, 2009; Jun). In this study the mechanism used is the number of boards of directors, independent board of commissioners, audit committee, and institutional ownership.

The agency theory proposed by Jensen \& Meckling (1976) states that if there is a separation between the owner as the principal and the manager as the agent running the company, there will be agency problems because each party will always try to maximize its utility function.

\section{RESEARCH METHODOLOGHY}

The population in this study are companies that list on the Indonesia Stock Exchange using the data from 2006 to 2013. This study uses secondary data obtained from the Indonesian Capital Market Directory and Database Indonesia Stock Exchange. Using path analysis does data analysis technique.

The main output of the results of this study is scientific publication; the results of this study will be published in the national journal. The additional output generated is the finding of model equations for testing various indicators that can explain the level of investor confidence in the performance of the manufacturing companies listed on the Indonesia Stock Exchange. 
From the conceptual framework in figure 1 then the equation model formed is as follows:

Equation model:

$\mathrm{Y}_{1}=\mathrm{p}_{1} \mathrm{X}_{1}+\mathrm{p}_{2} \mathrm{X}_{2}+\mathrm{p}_{3} \mathrm{X}_{3}+\mathrm{p}_{4} \mathrm{X}_{4}+\mathrm{e} 1$

$\mathrm{Y}_{2}=\mathrm{p}_{5} \mathrm{X}_{1}+\mathrm{p}_{6} \mathrm{X}_{2+} \mathrm{p}_{7} \mathrm{X}_{3}+\mathrm{p}_{8} \mathrm{X}_{4}+\mathrm{e} 2$

$\mathrm{Y}_{3}=\mathrm{p}_{9} \mathrm{X}_{1}+\mathrm{p}_{10} \mathrm{X}_{2}+\mathrm{p}_{11} \mathrm{X}_{3}+\mathrm{p}_{12} \mathrm{X}_{4}+\mathrm{p}_{13} \mathrm{Y}_{1}+\mathrm{p}_{14} \mathrm{Y}_{2}+\mathrm{e} 3$

Where:

$\mathrm{P}_{1.14}=$ Coefficient

$\mathrm{Y}_{1} \quad=$ Accounting Conservatism

$\mathrm{Y}_{2} \quad=$ Earning Management

$\mathrm{Y}_{3} \quad=$ Investor Confidence Level

$\mathrm{X}_{1} \quad=$ Board of Directors Size

$\mathrm{X}_{2} \quad=$ Size of Board of Commissioners

$\mathrm{X}_{3} \quad=$ Number of Audit Committee

$\mathrm{X}_{4} \quad=$ Institutional Ownership

$\mathrm{E}_{1,2,3} \quad=$ Error Term

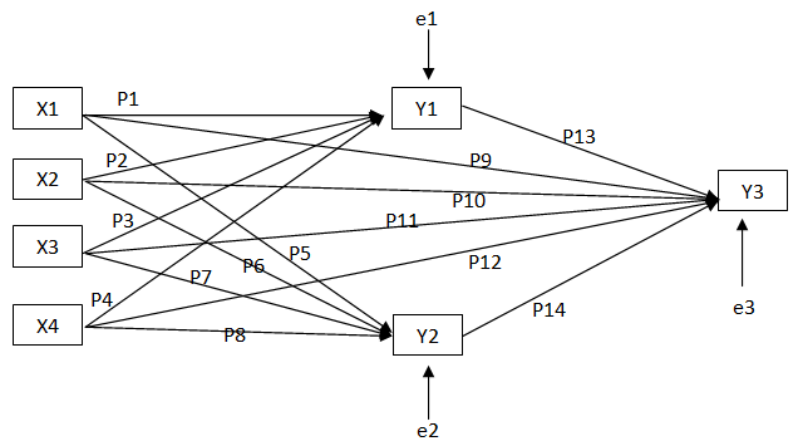

Figure 1 Conceptual Framework

\section{FINDINGSAND DISCUSSION}

\section{The Influence of Corporate Governance Mechanisms on Accounting Conservatism}

This research failed to find any significant influence between corporate governance mechanism and the quality of financial statements. Accounting conservatism and earnings management are simultaneously and partially unaffected by boards of directors, commissioners, audit committees, institutional ownership. This finding does not support the findings of Chtorou, Bedard, and Courteau (2001) who have investigated that corporate governance practices have an influence on the quality of financial information.

The board of directors has no effect on conservatism. However, a positive sign can mean that the size or number of the board of commissioners is expected to reduce the conflict of interest between stakeholders and increase investor confidence. The magnitude of the board of commissioners can be viewed as a means to provide input and control the opportunistic behavior of directors and management the board of commissioners has no effect on conservatism. These results do not support the findings of Coller and Gregory (1999), which reveal that the more the number of members of the board of commissioners within a company, the monitoring function of the board of directors can be run better, so that companies will avoid fraudulent financial reporting. While Yermack (1996) and Jensen (1993) found the number of boards of commissioners as one of the corporate governance mechanisms negatively affect the relationship between accounting conservatism and firm value. When viewed from a negative sign on the beta coefficient, this result agrees to state that an increasingly high number of boards of commissioners are unlikely to reduce the

Table 1 Operational Definition of Variables

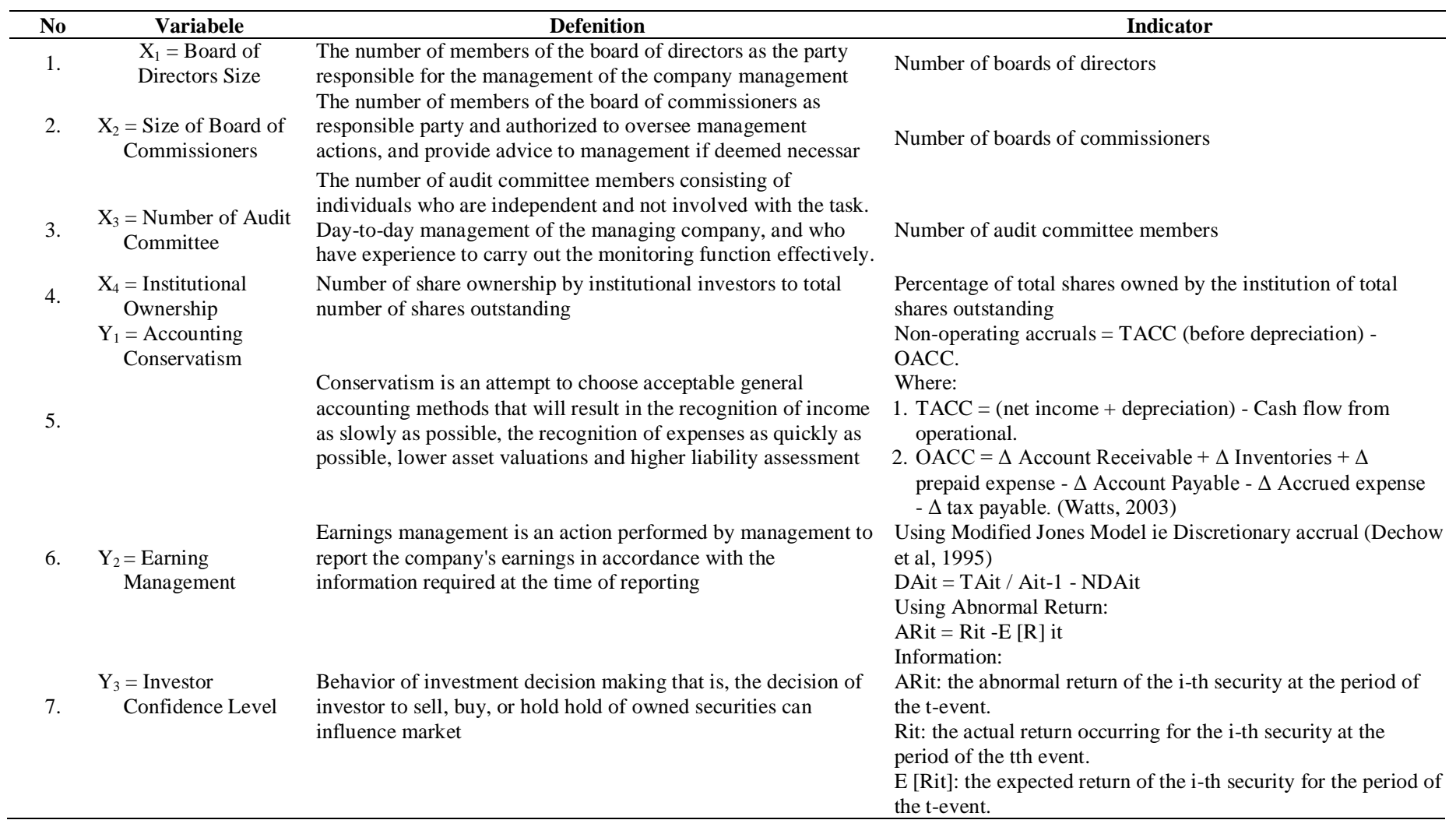


use of conservative accounting principles. In addition, the audit committee has no effect on conservatism and Institutional ownership has no effect on accounting conservatism, with a negative beta coefficient.

\section{Influence of Corporate Governance Mechanism on Profit Management}

The test results found that the corporate governance mechanism has no effect on earnings management. Judging from the beta coefficients that indicate a positive sign is only the board of directors, meaning that if the size of the board of directors the greater the company will tend to take profit management action. The negative sign on the board of commissioners, audit committee and institutional ownership means that the greater the number of boards of commissioners, audit committee, institutional ownership will reduce the happening of earnings management in the company.

The findings of this study rejected the research hypothesis, failed to find the effect of corporate governance on earnings management. In line with Dechow et al (1996), which also found that the number of boards of directors has no effect on earnings management. This means that the change in the size of the board of directors, will not affect corporate earnings management actions.

Testing the influence of board of commissioner to earnings management reject the research hypothesis, Similarly, the board of commissioners declared no effect on earnings management. The examination of the effect of institutional ownership on earnings management is also unsuccessful. Thus rejecting the findings of Jensen and Meckling (1976) and Morkck et al (1982) which found a negative influence of institutional ownership of earnings management.

\section{Influence of Corporate Governance Mechanism, Accounting Conservatism and Profit Management to Investor Trust}

Investor confidence in a company is influenced by various factors, such as management of quality, company ability in producing high financial performance in accordance with stakeholder expectations, and presentation of quality financial reports. In this study, the quality of financial statements proxies with accounting conservatism and earnings management is expected to affect investor confidence in investment decisionmaking. The level of investor confidence is also suspected to be affected by GCG mechanisms measured using board of directors, board of commissioners, audit committees, institutional ownership.

The test results found that simultaneously corporate governance mechanisms and the quality of financial statements affect the level of investor confidence. Investor confidence is measured by using investment decision-making behavior, i.e., the decision of an investor to sell, buy, or hold of any securities owned may affect the market. But what has a partial effect on investor confidence is institutional ownership and earnings management. Negative coupled coefficient beta means that greater institutional ownership will increase investor confidence. While earnings management is said to have a negative effect on investor confidence, meaning if the lower earnings management actions will increase investor confidence. Thus the hypothesis of this study is acceptable.
Although this research fails to find the effect of accounting conservatism on investor confidence, it does not mean that conservatism has no impact on the presentation of financial statements. The financial statements should be supplemented by voluntary disclosure of valuable off-balance-sheet information for investors. Such information such as research and development, human resources, information technology, corporate strategy and so forth. Otherwise the information users will assume the information presented in the financial statements to be meaningless. The rise of conservatism shows the failure of conventional accounting in presenting accounting numbers that have high value relevance. Quality accounting information is useful for investors to decrease asymmetric information and increase company value.

Furthermore, this study also wanted to find out how the role of corporate governance mechanism and the quality of financial statements as intermediary variables are proxies by accounting conservatism and earnings management to the level of investor confidence. When viewed from table 4 the comparison showing the beta value in each equation is done to see how the relationship of each variable of corporate governance mechanism namely the board of directors (X1), commissioner (X2), audit committee (X3), institutional ownership (X4) To investor confidence (Y3), whether it has a direct relationship or make the quality of financial statements as measured by accounting conservatism (Y1) and earnings management (Y2) as intervening variables.

Table 2 Relationship between Variables

\begin{tabular}{lccccc}
\hline No. & $\begin{array}{c}\text { Indirect } \\
\text { Relationship }\end{array}$ & Result & $\begin{array}{c}\text { Direct } \\
\text { Relationship }\end{array}$ & Result & Conclusion \\
\hline 1. & $\mathrm{X} 1-\mathrm{Y} 1-\mathrm{Y} 3$ & 0.008299 & $\mathrm{X} 1-\mathrm{Y} 3$ & 0.236 & Direct \\
2. & $\mathrm{X} 2-\mathrm{Y} 1-\mathrm{Y} 3$ & -0.010320 & $\mathrm{X} 2-\mathrm{Y} 3$ & -0.237 & Indirect \\
3. & $\mathrm{X} 3-\mathrm{Y} 1-\mathrm{Y} 3$ & 0.000258 & $\mathrm{X} 3-\mathrm{Y} 3$ & -0.003 & Indirect \\
4. & $\mathrm{X} 4-\mathrm{Y} 1-\mathrm{Y} 3$ & -0.006750 & $\mathrm{X} 4-\mathrm{Y} 3$ & 0.202 & Direct \\
5. & $\mathrm{X} 1-\mathrm{Y} 2-\mathrm{Y} 3$ & -0.045050 & $\mathrm{X} 1-\mathrm{Y} 3$ & 0.236 & Direct \\
6. & $\mathrm{X} 2-\mathrm{Y} 2-\mathrm{Y} 3$ & 0.003927 & $\mathrm{X} 2-\mathrm{Y} 3$ & -0.237 & Indirect \\
7. & $\mathrm{X} 3-\mathrm{Y} 2-\mathrm{Y} 3$ & 0.002079 & $\mathrm{X} 3-\mathrm{Y} 3$ & -0.003 & Indirect \\
8. & $\mathrm{X} 4-\mathrm{Y} 2-\mathrm{Y} 3$ & 0.028413 & $\mathrm{X} 4-\mathrm{Y} 3$ & 0.202 & Direct \\
\hline
\end{tabular}

The summary shown in table 2 can be seen that the size of the board of commissioners and audit committee has an indirect relationship to investor confidence. This means that the quality of financial statements with accounting conservatism and earnings management indicators is a variable that mediates the board of commissioners and audit committees in influencing investor confidence. The negative sign found in the coefficient indicates that if accounting conservatism and earnings management is lower then investor confidence will increase.

The size of the board of directors and institutional ownership has a direct relationship with the level of investor confidence. The greater the size of the board of directors will be able to increase investor confidence. Similarly with institutional ownership, if the portion of institutional ownership is greater then it will increase investor confidence to the company. But the effect test results are not able to prove the direct influence of the board of directors on the level of investor confidence. Because the test results state that there is no influence between the board of directors and the level of investor confidence.

Corporate governance mechanisms that have a direct and positive effect on investor confidence are only institutional ownership. The quality of financial statements proxies with 
accounting conservatism and earnings management suspected as an intermediary variable for constitutional ownership is not proven. Because the results show that constitutional ownership can directly affect the level of investor confidence. This means that this study proves that greater institutional ownership will increase investor confidence.

\section{CONLUSSION AND RECOMMENDATION}

The corporate governance mechanisms measured by using boards of directors, audit committees, independent commissioners and institutional ownership have no effect on the quality of financial statements. The quality of financial statements as measured by accounting conservatism as well as earnings management, based on signification testing simultaneously and partially rejects the proposed research hypothesis. This means that this study does not find the role of corporate governance mechanism in determining the quality of financial statements. The simultaneous testing of the effect of corporate governance mechanisms and the quality of financial statements on the level of trust accepts the research hypothesis. That the mechanism of corporate governance and the quality of financial statements affect the level of investor confidence. Partial test results found that the variables that have influence are institutional ownership and earnings management. While other variables such as boards of directors, audit committee, board of commissioners and accounting conservatism do not affect the level of investor confidence. Institutional ownership has a direct relationship to the level of investor confidence, without any intermediary variable of the quality of financial statements, accounting conservatism or earnings management. The greater institutional ownership will increase investor confidence in the company. Profit management actions undertaken by the firm will lower the level of investor confidence. This is evidenced by the negative coefficients on the test results. This means that this study successfully proves that earnings management has a negative effect on the level of investor confidence. The lower the profit management action will increase investor confidence. The amount of sample data is limited to 96 firms over a period of 4 years of observation, and limited to manufacturing firms, thus failing to prove the role of corporate governance mechanisms for improving the quality of financial statements that may affect investor confidence in the firm. Limitations in the selection of research variables may also be the reasons for rejection in some research hypotheses. Because the corporate governance mechanism uses only four measurement indicators and ignores other elements so the ability to explain the relation of the variables under study is very low, as evidenced by the $\mathrm{R}$ square value of less than $15 \%$ of the three equations used. This suggests that other variables not used in this study may be more dominant to explain or will affect the dependent variable.

\section{References}

Chtourou, S. M., J. Bédard, and L. Courteau, (2001). Corporate Governance and Earnings Management. Available at SSRN: http://ssrn.com/abstract=275053 or doi: $10.2139 /$ ssrn.275053.

Coller, P., dan A. Gregory, (1999). Audit committee activity and agency cost. Journal of Accounting and Public Policy, 18(4-5): 311-332.

Cornett, Marcia Millon; Alan J. Marcus; Hassan Tehranian. (2007). Corporate Governance and Pay-for-Performance: The Impact of Earnings Management. Journal of Financial Economics 87 (2), 357-373.

García-Meca, Emma; J. P. Sánchez-Ballesta. (2009). "Corporate Governance and Earnings Management: A Meta-Analysis". An International Review, 17(5), 594-610.

Givoly, Dan, Carla Hayn, dan Sharon P. Katz. (2008). Does Public Ownership of Equity Improve Earnings Quality? http://www.hbs.edu/research/pdf/09-105.

Healy, P. M, and P. J. Wahlen, (1999), A Review of the Earnings Management Literature and Its Implications for Standar Setting, Accounting Horizon. 13.

Jensen, M.C. (1993), The modern industrial revolution, exit and the failure of internal control systems, Journal of Finance, Vol. 48 No. 3, pp. 831-80.

Jensen, M.C. and Meckling, W.H. (1976), Theory of the firm: managerial behaviour, agency cost and ownership structure, Journal of Financial Economics, Vol. 3 No. 4, pp. 305-60.

Jun, SHI. (2010). Review on Researches of Earnings Management and Corporate Governance Mechanism. Journal of Modern Accounting and Auditing, 6(11).

Lev, B., and S. R. Thiagarajan. (1993). Fundamental information analysis. Journal of Accounting Research 31 (2): 190-215.10.2307/2491270

Ross L. Watts (2003) Conservatism in Accounting Part II: Evidence and Research Opportunities. Accounting Horizons: December 2003, Vol. 17, No. 4, pp. 287-301.

Wolk, H.I. and Michael G. Tearney. (1997). Accounting Theory. Fourth Edition, South Western College Publishing.

Yermack, D. (1996), Higher market valuations of companies with a small board of directors, Journal of Financial Economics, Vol. 40 No. 2, pp. 185-211.

Zhang, Xiao-Jun, Conservative Accounting and Equity Valuation (January 2000). Available at SSRN: https://ssrn.com/abstract=238197 or http://dx.doi.org/ $10.2139 /$ ssrn. 238197

\section{How to cite this article:}

Syafrida Hani and Hafsyah.2017, Good Corporate Governance Mechanisms in Measuring Quality of Financial Statements and Transfer Investor Levels. Int J Recent Sci Res. 8(5), pp. 17092-17096. DOI: http://dx.doi.org/10.24327/ijrsr.2017.0805.0280 